Netra Pal Singh ${ }^{1}$

Devender Singh ${ }^{2}$
JEL: 03

DOI:10.5937/industrija47-24578

UDC: 004.738.5:336.71(540)

004.5:159.9

Case Study

\title{
Chatbots and Virtual Assistant in Indian Banks
}

Article history:

Received: 25 October 2019

Sent for revision: 15 November 2019

Received in revised form: 2 December 2019

Accepted: 3 December 2019

Available online: 31 December 2019

\begin{abstract}
This paper discusses the adoption of chatbots and virtual Assistants by different category of banks (private sector banks and public sector banks) in India. The research paper presents a brief introduction of banking industry in India, history, characteristics, and architecture of chatbots and virtual assistants. The research paper also included basic features, way to connect, services offered, accuracy, technology providers of chatbots and virtual assistants implemented by Indian banks. Research paper concluded that Indian banks are aggressively investing in chatbots and virtual assistant technology but features are limited. Most of the questions answered by chatbots/ virtual assistant are routine for which data is already available on websites of the banks. Secondly, awareness of chatbots/ virtual assistants is very low among the customers and employees of the banks. It necessitates enhancement of existing capabilities of chatbots/ virtual assistant deployed by Indian banks and awareness with respect to usefulness among employees and customers
\end{abstract}

Keywords: Chatbot, Virtual Assistant, Indian Banks, Accuracy, Architecture, Rule Based, SIA, ABHi

\section{Čatbotovi i virtuelni asistent $u$ indijskim bankama}

Apstrakt: $\quad U$ ovom radu se govori o usvajanju čatbotova $i$ virtuelnih asistenata od strane razlicitih kategorija banaka (banke iz privatnog sektora $i$ banke iz javnog sektora) u Indiji. Istraživački rad obuhvata kratak uvod bankarske industrije u Indiji, istoriju, karakteristike $i$ arhitekturu čatbotova $i$ virtuelnih asistenata. Rad, takođe, uključuje osnovne karakteristike, način

\footnotetext{
${ }^{1}$ Management Development Institute, India, knpsingh@mdi.ac.in ; netra.singh@gmail.com

${ }^{2}$ Department of Business Administration, Aligarh Muslim University, India 
povezivanja, usluge koje se nude, tačnost, tehnologije dobavljača čatbotova $i$ virtuelnih asistenata koje implementiraju indijske banke. Na osnovu analize dostupnih podataka, zaključeno je da indijske banke agresivno ulažu u čatbotove i tehnologiju virtuelnog asistenta, ali mogućnosti su ograničene. Većina pitanja na koja odgovaraju čatbotovi / virtualni asistent je rutinska, i za odgovore na njih podaci su već dostupni na veb lokacijama banaka. Takođe, svest klijenata i zaposlenih u bankama o ovim tehnologijama je vrlo niska. Stoga je potrebno poboljšati postojeće mogućnosti pomenutih tehnologija koje su postavile indijske banke i svest o korisnosti među zaposlenima i klijentima.

Ključne reči: Čatbot, virtuelni asistent, indijske banke, tačnost, arhitektura, zasnovanost na pravilima, SIA, ABHi

\section{Introduction}

The Indian banking industry comprises of approximately 20 banks in the public sector, 22 banks in the private sector, 56 regional rural banks, 44 foreign-owned banks, 22 scheduled state cooperatives banks, 11 nonscheduled state cooperatives banks, 54 scheduled urban cooperative banks, 1488 non-scheduled urban cooperative banks and 364 district central cooperative banks. Banks of the public sector dominate approximately 80 per cent of the business share, transmitting relatively small fragments to its private rivals.

As a measure of reform in Indian Banking sector, on 30th Aug 2019, Indian Government decided to merge 10 large public sector banks into four banks. This will bring down the count of public sector banks to 12. It was decided that Punjab National Bank, Oriental Bank of Commerce and United Bank will be merged; Canara Bank and Syndicate Banks will be merged; Union Bank of India, Andhra Bank and Corporation Bank will be merged; Indian Bank and Allahabad Bank will be merged.

In order to achieve operational efficiencies, reduction in cost of operations and better financial control, banks in India are adopting the latest technologies. After the adoption of central banking system (core banking), Indian banks are heading towards implementation of emerging technologies like big data, analytics, machine learning, artificial intelligence (Al) and Internet of things (loT).

It is high growth stage of digitization in Indian banks. Dastur (2019) mentioned that after demonetization, numbers of ATM are stagnant at 0.22 million but point of sale (PoS) terminals for card swipes have grown to over 3.7 million. Bhakta (2019) reported that debit card swipes on Point of Sales (PoS) terminals jumped more than $27 \%$ in March 2019 compared to corresponding period last year. In contrast, ATM withdrawals grew at a slower pace of $15 \%$. 
ATM withdrawals remained almost stagnant at 890 million in March, 2019 against 869 million in October last year. In the same period UPI grew $62 \%$ to 781 million in March, 2019 against 482 million in October, 2018. Chitra (2019) mentioned that $\mathrm{Al}$ is everywhere from chatbots to clearing of cheques.

Presently, many banks in India are implementing chatbots and virtual assistant that are created using $\mathrm{Al}$ and machine learning technologies. Chatbots are also known as artificial conversational entity (ACE), chat robot, talk bot, IM bot, interactive agents, chatterbot or chatterbox. Chatbots have the ability to respond differently to varied keywords, learn, and adapt their own responses to suit diverse situations. Because of these features chatbots are helping in real-time communications, handling customer enquiries, and other aspects of businesses to optimize overall customer satisfaction. Customer service is the highest contributing segment for proliferation of chatbots \& virtual assistants with a $42.52 \%$ share (Pise, 2018). Chatbots \& Virtual Assistant can be embedded and used through any major messaging applications. Chatbots enable personalized services, reduction in waiting time for users, uninterrupted customer support, and a feedback channel to a large number of customers, and guaranteeing consumer satisfaction.

Business Wire (2018) reported that the global intelligent virtual assistant markets have reached a value of nearly US\$1.7 Billion in 2017. This value is projected at $\$ 9$ billion by 2023 which will result in to a CGAR of $32 \%$. It means that the chatbots growth in the recent years and in near future will be phenomenal which is evident from this data. Keeping in view importance of chatbots/virtual assistant in future, deployment of these technologies by the Indian banks is analyzed in this research paper. The research paper is divided in to seven sections starting with the section of introduction. It is followed by research methodology (including context, objectives, methods of data collection \& analysis) in section 2. Historical perspective of chatbots is presented in section 3 followed by review of literature in the context of characteristics in section 4. Architecture of chatbot/ virtual assistant is presented in section 5. Implementation of chatbots / Virtual Assistants by Indian Banks is presented in section 6 . Analysis, results and suggestions are listed in last section 7.

\section{Research Methodology}

\subsection{The Context}

Technology has a significant impact on our day to day life and banking is not an exception. Since the advent of central banking systems, banking sector has embraced the technological advances in terms of internet banking, mobile 
banking, introduction of biometrics, big data analytics, artificial intelligence, Internet of Things (IOT). Banking organization across the world are leaning towards technology to provide better experience to their customers. Banking has evolved from standing in long queues in bank branches to banking through digital devices. With the advent of emerging technologies in different spheres of the business, banking industry is not an exception. The banks across the world and in India are focusing on harnessing the power of the emerging technologies such as Big data, Big Data Analytics, Internet of Things, and artificial intelligence.

\subsection{Objective and Research Questions}

Large number of research papers are available in the literature related to application of information technology such as core banking solution, internet banking, mobile banking etc. However, not much is reported in the literature related to usage of emerging technologies such as Al, loT, Big Data, analytics, etc. in Indian banking sector. This paper is an attempt to study the utilization of the artificial intelligence and natural language processing in Indian banks with respect to the usage of Chatbots/Virtual assistants and fill the gap in the literature on the subject. Select Indian banks both public and private sector has launched chatbots/virtual assistants in order to decrease the operational costs and increase the customer satisfaction by providing the banking services through these chatbots/virtual assistants. With the present level of usage of chatbots/ virtual assistants, this research paper attempted to answer the following research questions.

What is present status of chatbots/virtual assistant's implementation by Indian Banks?

What are the ways to connects chatbots/ virtual assistants implemented by Indian Banks?

What are the services offered by chatbots/virtual assistants implemented by Indian Banks?

What is the level of accuracy by chatbots/virtual assistants implemented by Indian Banks?

\subsection{Research Approach: Data \& Analysis}

The approach followed in the paper is exploratory cum descriptive. It is an attempt to analyze the different chatbots used by different Indian banks with a view to answer above research questions. The focus has been only on Indian private and public sector banks. In all 12 Indian banks have implemented chatbots/virtual assistants. In addition, Allahabad bank reported that its app 'emPower' is scheduled to get major enhancements like chatbot and AI based e-commerce payments (PTI, 2018). 
Three sets of data are used in this research paper, i.e., two sets of primary data as well as secondary. One set of primary data are collected in the form of answer of the questions asked to chatbots/ virtual assistants implemented by Banks in India. The analysis of this data is in the form of correct and incorrect answers by chatbots/ virtual assistants. Another set of primary data collected from the select employees of Indian Banks who are considered to be aware of various features of chatbots/ virtual assistants. The questions were centered on four research questions mentioned in this section. In all 55 employees of banks in the NCR region were interviewed for the purpose.

Secondary data is collected from sources which are in public domain such as website of the banks and technology provider companies, press releases by banks \& news websites, literature available in research journals, blogs by experts on the topic, research agencies report, etc. Data is analyzed to identify key parameters as listed in section 6 of chatbots / virtual assistants in the context of Indian Banks. These two sets of data are used to understand the dynamics of usage of chatbots/ virtual assistants in the operating environment of Indian banks with a view to suggest future direction of research and also to answer research questions.

\section{Chatbots/ Virtual Assistant- Historical Perspective}

The first chatbot was came into being in 1966. This was called ELIZA. It was a text messaging-based agent developed at MIT Artificial Intelligence Laboratory (Weizenbaum, 1966). The platform basically worked on pattern matching and substitution methodology.

In 1972, PARRY was introduced to the world. This was written by Kenneth Colby who was a psychiatrist at Stanford University. ELIZA was referred as "tongue-in-check" simulation of a Rogerian therapist, PARRY was mentioned to be simulating a person with paranoid schizophrenia. PARRY implemented a crude model of the behavior of a person with paranoid schizophrenia based on concepts, conceptualizations, and beliefs. In 1981, a British Programmer Rollo Carpenter created a chatterbot with name Jabberwacky. The aim of the chatterbot was to simulate natural human chat in an interesting, entertaining and humorous manner. It was mainly designed to mimic human interaction and to carry out conversations with users. It was not designed to carry out any other functions. The ultimate intention of creating this bot was that the program move from a text-based system to a fully voice operated module which could learn directly from sound and other sensory inputs. Its creator believes that it can be incorporated into objects around the home such as robots or talking pets, intending both to be useful and entertaining, keeping people company. The internet version of the bot was launched in 1997 
(Source: Wikipedia). The evolved version of Jabberwacky was launched in 2008 with the name "Cleverbot" (www.cleverbot.com). It has joined twitter in May 2011 and has 23815 followers.

In 1991, Creative Labs released a chatbot with named "Dr. Sbaitso". The chatbot was for MS-DOS based personal Computers. It was an artificial intelligence speech synthesis program. The program "conversed" with the user as if it were a psychologist, though most of its responses were along the lines of "WHY DO YOU FEEL THAT WAY?" rather than any sort of complicated interaction. When confronted with a phrase it could not understand, it would often reply with something such as "THAT'S NOT MY PROBLEM" (Source: https://en.wikipedia.org/wiki/Dr.Sbaitso). Underlying algorithm ${ }^{3}$ resembles the one ELIZA is based on (Wei et al., 2018).

In 1995, another chatbot was introduced to the world with name ALICE. The extended form of ALICE was Artificial linguistic internet computer entity. ALICE was a natural language processing chatbot which engages in conversation with a human by applying some heuristically pattern matching rules to the human's input. This chatbot was composed by Richard Wallace.

In 2001, ActiveBuddy Inc., introduced a chatbot with name "SmarterChild". It was a brainchild of Robert Hoffer, Timothy Kay and Peter Levitan. The idea for instant messaging bots came from the team's vision to add natural language comprehension functionality to the increasingly popular instant messaging and SMS platforms. SmarterChild acted as a showcase for the quick data access and possibilities for fun personalized conversation that the company planned to turn into customized, niche specific products. ActiveBuddy changed its name to Colloquis and prospered selling a superior automated customer service SAS offering to large companies. Microsoft acquired Colloquis in 2007 for $\$ 46$ Million and proceeded to decommission SmarterChild and discontinue the Automated Service Agent business as well (Hoffer, 2015).

In 2011, Apple released the popular virtual assistant Siri. The assistant Siri uses voice queries and a natural-language user interface to answer questions, make recommendations, and perform actions by delegating requests to a set of Internet services. The software adapts to users' individual language usages, searches, and preferences, with continuing use. Siri is a spin-off from a project originally developed by the SRI International Artificial Intelligence Center. Its speech recognition engine was provided by Nuance Communications, and Siri uses advanced machine learning technologies to function. Its original American, British, and Australian voice actors recorded

\footnotetext{
${ }^{3}$ https://chatboten.com/chatbots-evolution/
} 
their respective voices around 2005, unaware of the recordings' eventual usage in Siri. The voice assistant was released as an app for iOS in February 2010, and it was acquired by Apple two months later. Siri was then integrated into iPhone 4S at its release in October 2011. Singh (2019) reported that according to Futuresource Consulting, Siri is the most popular virtual assistant across the world with a $35 \%$ market share.

In 2011, Watson was released by IBM. Watson was created as a question answering (QA) computing system that IBM built to apply advanced natural language processing, information retrieval, knowledge representation, automated reasoning, and machine learning technologies to the field of open domain question answering. It was named after IBM's founder and first CEO, industrialist Thomas J. Watson. In February 2013, IBM announced that Watson software system's first commercial application would be for utilization management decisions in lung cancer treatment at Memorial Sloan Kettering Cancer Center, New York City, in conjunction with WellPoint (now Anthem) (News Release, 2013).

In 2012, "Google Now" chatbot/ virtual assistant was introduced by Google. For the first time it was included in Android 4.1 version on the Galaxy Nexus smartphone. The service became available for iOS in 2013, without most of its features. In 2014, Google added Now cards to the notification center in Chrome OS and in the Chrome browser. Later, however they removed the notification center entirely from Chrome. In 2016, the evolved version of Google Now was introduced with name Google Assistant (https://en.wikipedia.org/wiki/Google_Now). It market share is $9 \%$ (Southern, 2019).

In 2014, Amazon introduced their virtual assistant with name "Alexa". Alexa is capable of voice interaction, music playback, making to-do lists, setting alarms, streaming podcasts, playing audiobooks, and providing weather, traffic, sports, and other real-time information, such as news. Alexa can also control several smart devices using itself as a home automation system. Users are able to extend the Alexa capabilities by installing "skills" (additional functionality developed by third-party vendors, in other settings more commonly called apps such as weather programs and audio features). Lynskey (2019) mentioned that voice assistants epitomize the tension between efficiency and privacy in the context of Alexa.

In 2014, Microsoft introduced their virtual assistant with name "Cortana". The virtual assistant was named after Cortana, who was a synthetic intelligence character in Microsoft's Halo video game franchise originating in Bungie folklore, with Jen Taylor, the character's voice actress, returning to voice the personal assistant's US-specific version. Cortana can set reminders, 
recognize natural voices without the requirement for keyboard input, and answer questions using information and web results from the Bing search engine. Warren (2019) reported that Cortana isn't dead, but it's no longer an Alexa competitor.

In 2016, Google introduced another virtual assistant name "Allo" an instant messaging mobile app. Allo is based on phone numbers. Allo's "Smart reply" feature uses Google's machine learning technology to suggest a reply to the last message, which can be selected from a few options. The feature also analyzes images sent to the user in order to suggest responses. Similar to the smart reply feature seen in Google's Inbox app, it learns from the user's behavior to adapt its suggestions over time (https://en.wikipedia.org/wiki/Google_Allo).

In 2016, Microsoft released another chatbot with name "Tay" after the acronym "Thinking about you" via twitter. The bot was shut down after 16 hours of its release as the bot posted inflammatory and offensive tweets. In the present context Google Assistant, Apple's Siri, Microsoft's Cortana and Amazon's Alexa are the major players in the global market.

\section{Review of Literature: Characteristics of Chatbots/ Virtual Assistants \& Indian context}

This section presents review of literature in the context of characteristics of chatbots / virtual assistants. The review has two objectives. The first one about characteristics of chatbot/ virtual assistants. The second one to list literature on chatbot / virtual assistant research in the Indian context. It is well known fact that a chatbot/ virtual assistant needs to have a certain characteristic in order to increase its usability among the users. If the chatbot is lacking those key ingredients, it may not be used by the users in the long run. On internet there are plethora of sites highlighting the key characteristics, a chatbot should have. Apart from internet there are large number of research papers available on assessment of chatbot features. Some of these researches are reviewed here.

Wei et al. (2018) had made an attempt to study the various features of the chatbot. As per their work, the major characteristics of a chatbot are - selfconsciousness, humor, purity, Intelligence Quotient, Emotional Quotient, memory, self-learning and charisma. These characteristics were assessed by training and testing on various datasets. Piccolo et al. (2019) conducted a study on first time users of chatbot. The study identified chatbots characteristics such as - Appropriate interaction style, Appropriate tasks and Towards Trustfulness. Jain et al. (2018) conducted a study of chatbot users 
and found that the chatbot should perform its main functionality, should have conversational intelligence, chatbot personality should match its domain and should have a good interface. They mentioned further that chatbot designers should ensure that chatbots understand and sustain conversation context, provide a clear and ongoing indication of the chatbot capabilities, engage in small talk, indicate when the chatbot fails to perform a task, and end a conversation gracefully

Kuligowska (2015) studied chatbots in the context of Polish market. He found that the visual look of the chatbot, form of implementation on the website, speech synthesis unit, built in knowledge base, presentation of knowledge and additional functionalities, conversational abilities and context sensitiveness, personality traits, personalization options and emergency responses in unexpected situations are key features of a chatbot/virtual assistant. He also mentioned that the quality of chatbots can be assessed on different parameters like visual look, form of implementation on the website, speech synthesis unit, built-in knowledge base, presentation of knowledge and additional functionalities, conversational abilities and context sensitiveness, personality traits, personalization options, emergency responses in unexpected situations, possibility of rating chatbot and the website.

Bluewolf (2019) had mentioned seven characteristics a good chatbot should have. These are Conversational maturity, Omni-Capable, Integration with $\mathrm{CRM}$, emotionally intelligent, Free to explore, Autonomous reasoning and pretrained. Rollason (2019) has mentioned that a chatbot should have eleven characteristics. These are Ability to learn, Ability to fail usefully, Ability to transfer complex request to human agent, accessible, secure, explainable, knowledge centered service, Omni channel, free to explore and analytical.

Maya (2017) has suggested ten features which a chatbot should have. These are conversational breaks, exit button, make it visual, social media integration, subscriptions, payment plugin, broadcasting, Analytical, Go personal and could use NLP. Kim (2018) has suggested that a chatbot should have the ability to use NLP, it should be emotionally intelligent, should be smart and analytical, should be user focused, should have a subscription feature, should have broadcasting skills, should be CRM ready, and should be GDPR(General Data Protection Regulations) complaint. Chatbots should also be able to understand the context, should understand the intention of the user, should be capable of entity and linguistic annotation.

The use of chatbots has continued until the present day in the form of apps that provide an illusion of conversation with a human as well as in areas such as education, information retrieval, business, and e-commerce, for example, 
as automated online assistants to complement or even replace humanprovided services in a call center (McTear et al., 2016).

Zamora $(2017 \mathrm{a}, \mathrm{b})$ mentioned that curiosity and interest may spark an initial interaction with a chatbot but in order to add more value to ongoing interactions there is a need to define a broadly acceptable role that has a define purpose. He studied the chatbots / virtual assistant in the Indian context with three objectives, i.e., (i) understand user perception and expectations of chatbots, (ii) surface preferences for input modality and (iii) identify domains where chatbots can add meaningful purpose.

Vaidyam et al (2019) defined chatbots as digital tools existing either as hardware or software that use machine learning and artificial intelligence methods to mimic human like humanlike behaviors and provide a taskoriented framework with evolving dialogue able to participate in conversation. Gupta and Sharma (2019) tested three hypotheses, i.e., (i) relationship between observed utility and the attitude of consumers towards chatbots, (ii) relationship between observed accessibility and the attitude of consumers towards chatbots, and (iii) relationship between observed threats and awareness and the attitude of consumers towards chatbots.

\section{Architecture of chatbot/virtual assistant}

Chatbot is an intelligent piece of software that is capable of communicating and performing similar actions similar to a human. Chatbots are used a lot in customer interaction, marketing on social network sites and instantly messaging the client.

Figure 1. Working of Al Chatbot

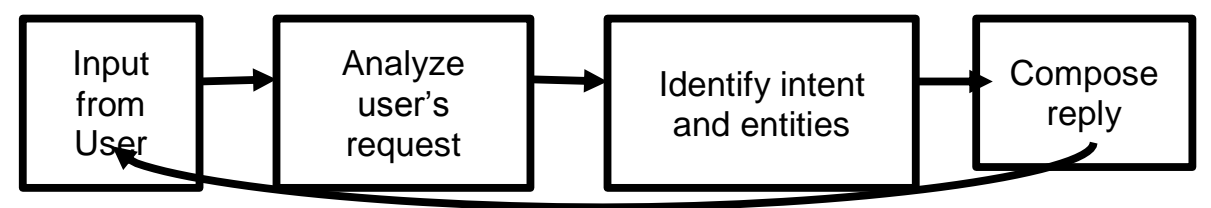

Source: https://www.drift.com/learn/chatbot

The chatbot architecture follows two different models. These are on the basis of as to how they operate. These models are Rule based and Artificial intelligence-based models. A rule based chatbot uses predefined input patterns and responses. It then uses some type of heuristic approach to 
select the appropriate response. It is widely used in the industry to make goaloriented chatbots where we can customize the tone and flow of the chatbot to drive our customers with the best experience. Artificial intelligence models are not based on some predefined responses.

Figure 2. Working of Rule Based Chatbot

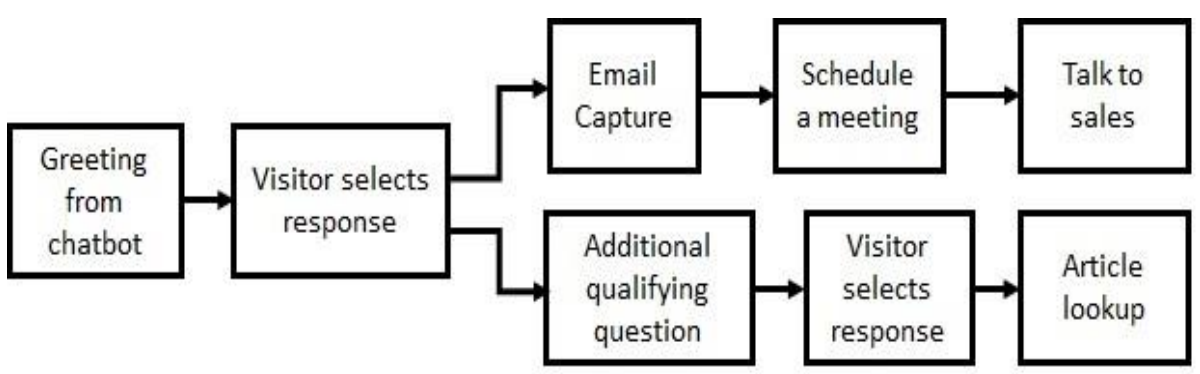

Source: www.drift.com/learn/chatbot

For working of a chatbot the first and foremost thing is understanding the user inputs. These inputs are processed through text classifiers, algorithms, artificial neural networks and natural language understanding. As part of text classification, the words and sentences are segregated into meaningful intent. Matching of patterns is used for these classifications. Once the intent is understood the chatbot needs to respond with appropriate message, which is done by natural language understanding.

\section{Chatbots/ Virtual Assistants implemented by Indian Banks}

In India all categories of banks - public sector banks and private banks are making use of artificial technologies and have deployed Al based chatbots and Virtual Assistants in the recent past. Many facets of these deployments are explained in the subsection of this section. The first section is about basic data such as Name of bank, Name of chatbot, Type of bank, Year of chatbot implementation and ways to connect to the chatbot. The second section is about services handled by chatbots and virtual assistants.

\subsection{Basic features and ways to connect chatbots/ virtual assistant}

The basic features data of chatbots and ways to connect with the chatbot/ virtual assistant software's for 12 banks are given in table 6.1. It can be inferred from the data given in table 6.1 that chatbots implementation in Indian 
Singh N.P. \& Singh D.: Chatbots and Virtual Assistant in Indian Banks

banks started during 2016 to 2019 and majority of private banks have implemented these technologies. The services of chatbot and virtual assistants are available $24^{\star} 7$ in all the 12 banks which have implemented the services except for Canara Bank. In Canara Bank the robots are installed in the bank premises and operate during bank working hours. The banks have provided different ways to connect to the chatbots. In most of the cases, the chatbots are accessible through the bank websites.

Table 1. Chatbots and Virtual Assistants, ways to connect in Indian Banks

\begin{tabular}{|c|c|c|c|c|c|c|c|}
\hline $\begin{array}{l}\text { SI } \\
\text { No }\end{array}$ & $\begin{array}{l}\text { Name of } \\
\text { Bank }\end{array}$ & $\begin{array}{l}\text { Chatbot } \\
\text { Name }\end{array}$ & $\begin{array}{l}\text { Type of } \\
\text { Bank }\end{array}$ & $\begin{array}{l}\text { Year of } \\
\text { Implem } \\
\text { entation }\end{array}$ & $\begin{array}{l}\text { Avail } \\
\text { ability }\end{array}$ & Ways to connect & Source \\
\hline 1 & $\begin{array}{l}\text { HDFC } \\
\text { Bank }\end{array}$ & EVA & Private & 2017 & $24^{\star} 7$ & $\begin{array}{l}\text { Bank's Website, } \\
\text { Google Assistant, } \\
\text { Amazon Alexa }\end{array}$ & Website \\
\hline 2 & $\mathrm{ICICI}$ Bank & $\mathrm{iPal}$ & Private & 2017 & $24^{\star} 7$ & $\begin{array}{l}\text { Bank's Website, } \\
\text { mobile bank }\end{array}$ & $\begin{array}{l}\text { Rawal } \\
\text { (2017) }\end{array}$ \\
\hline 3 & Yes Bank & $\begin{array}{l}\text { Yes } \\
\text { Robot }\end{array}$ & Private & $\mathrm{NK}^{*}$ & $24^{\star} 7$ & $\begin{array}{l}\text { Facebook } \\
\text { Messenger, Bank's } \\
\text { Website }\end{array}$ & Website \\
\hline 4 & $\begin{array}{l}\text { IndusInd } \\
\text { Bank }\end{array}$ & $\begin{array}{l}\text { Indusassi } \\
\text { st }\end{array}$ & Private & 2018 & $24^{\star} 7$ & $\begin{array}{ll}\text { Alexa, } & \text { Bank's } \\
\text { Website } & \end{array}$ & Website \\
\hline 5 & $\begin{array}{l}\text { Kotak } \\
\text { Mahindra } \\
\text { Bank }\end{array}$ & Keya & Private & 2018 & $24^{\star} 7$ & Bank's Website & Website \\
\hline 6 & Axis Bank & Axis Aha & Private & 2018 & $24^{\star} 7$ & $\begin{array}{l}\text { Bank's Website, Axis } \\
\text { mobile apps }\end{array}$ & Website \\
\hline 7 & $\begin{array}{l}\text { City Union } \\
\text { Bank }\end{array}$ & $\begin{array}{l}\text { CUB } \\
\text { Lakshmi } \\
\text { Robot }\end{array}$ & Private & 2016 & $24^{\star} 7$ & $\begin{array}{ll}\text { Bank's } & \text { Website, } \\
\text { Facebook }\end{array}$ & Website \\
\hline 8 & $\begin{array}{l}\text { State Bank } \\
\text { of India }\end{array}$ & SIA & Public & 2017 & $24^{\star} 7$ & Bank's website & $\begin{array}{l}\text { Shetty } \\
(2017)\end{array}$ \\
\hline 9 & $\begin{array}{l}\text { Andhra } \\
\text { Bank }\end{array}$ & $\overline{\mathrm{ABHi}}$ & Public & 2019 & $24^{\star} 7$ & Bank's Website & $\begin{array}{l}\text { UNI } \\
(2019)\end{array}$ \\
\hline 10 & $\begin{array}{ll}\text { Bank of } \\
\text { Baroda }\end{array}$ & ADI & Public & NA & $24^{\star} 7$ & Bank's Website & Website \\
\hline 11 & $\begin{array}{l}\text { Union } \\
\text { Bank of } \\
\text { India }\end{array}$ & UVA & Public & 2017 & $24^{\star} 7$ & Bank's Website & Website \\
\hline 12 & $\begin{array}{l}\text { Canara } \\
\text { Bank }\end{array}$ & $\begin{array}{l}\text { Mitra and } \\
\text { Candi } \\
\text { Robot }\end{array}$ & Public & 2017 & $\begin{array}{l}\text { Durin } \\
g \\
\text { bank } \\
\text { hrs }\end{array}$ & At bank premises & $\begin{array}{l}\text { Patranob } \\
\text { is and } \\
\text { Gopal } \\
(2017)\end{array}$ \\
\hline 13 & \multicolumn{7}{|c|}{ IDBI Bank: Floated RFP for chatbot } \\
\hline 14 & $\begin{array}{l}\text { Federal } \\
\text { Bank }\end{array}$ & \multicolumn{6}{|c|}{$\begin{array}{l}\text { It has launched a chatbot based virtual assistant in the bank' } \\
\text { application FedMobile in partnership with NIKI.ai (Bhakta (2018a) }\end{array}$} \\
\hline
\end{tabular}

However, banks like HDFC bank and Yes bank have provided an integration of the chatbot with Amazon's Alexa. The integration with Alexa provides the 
ease of banking at the comfort of home. Banks like ICICI Bank and Axis Bank has extended the chatbot feature through mobile apps which provides the customer an option of banking on the go. Easy accessibility and ease of use of the chatbots may majorly contribute to the adoption of this latest technology across the banks' customer base. India being a country of multiple languages, availability of these chatbots in vernacular languages may also prove beneficial.

\subsection{Services offered by Chatbots in Indian Banking Sector}

The chatbots provided by banks are in initial stages and are able to provide only a limited set of banking services. The services offered by these chatbots for each bank are provide in Table 2. It can be seen that in most of the cases the chatbots are able to answer general queries related to banking services.

Table 2. Services offered by Chatbots and Virtual Assistants in Banks in India

\begin{tabular}{|c|c|c|c|}
\hline S.N & Name of Bank & Services offered & Source \\
\hline 1 & HDFC Bank & All general queries except payments & Website \\
\hline 2 & ICICl Bank & $\begin{array}{l}\text { All general queries, bill pay, fund transfer, } \\
\text { recharge. }\end{array}$ & Rawal (2017) \\
\hline 3 & Yes Bank & $\begin{array}{l}\text { Check balance, recent transactions, send money, } \\
\text { recharge phone, pay bills, book FD/RD, check loan } \\
\text { eligibility, manage credit card, hotlist debit card and } \\
\text { apply for } 25+\text { YES BANK products and services }\end{array}$ & Website \\
\hline 4 & IndusInd Bank & $\begin{array}{l}\text { General queries, Account balance, transfer funds, } \\
\text { pay credit card bills }\end{array}$ & Website \\
\hline 5 & $\begin{array}{l}\text { Kotak } \\
\text { Mahindra } \\
\text { Bank }\end{array}$ & General queries, fund transfer, fix deposits, & Website \\
\hline 6 & Axis Bank & $\begin{array}{l}\text { General queries, cheques book request, Block } \\
\text { Card, bill payment, Recharge, fund transfer, } \\
\text { Manage limits on cards }\end{array}$ & Website \\
\hline 7 & $\begin{array}{l}\text { City Union } \\
\text { Bank }\end{array}$ & General Queries, Almost all services & Website \\
\hline 8 & $\begin{array}{l}\text { State Bank of } \\
\text { India }\end{array}$ & All general queries. & Shetty (2017) \\
\hline 9 & Andhra Bank & $\begin{array}{l}\text { All general queries, balance check, ordering } \\
\text { cheques book, mini statements, recent } \\
\text { transactions. }\end{array}$ & UNI (2019) \\
\hline 10 & $\begin{array}{ll}\text { Bank of } \\
\text { Baroda }\end{array}$ & All general queries & Website \\
\hline 11 & $\begin{array}{l}\text { Union Bank of } \\
\text { India }\end{array}$ & All general queries & Website \\
\hline 12 & Canara Bank & Robot, works similar to bank employee. & $\begin{array}{l}\text { Patranobis } \\
\text { and Gopal } \\
(2017)\end{array}$ \\
\hline
\end{tabular}

However, some banks have achieved a greater maturity and are able to provide most of the banking services to the customers through the chatbot. A 
general review of the Table 2 reveals that Yes bank is leading from the front and provides almost all banking services to its customers through the chatbot. Handling all banking processes through the chatbot may certainly have a positive impact on the operational cost of the bank.

\subsection{Chatbots/ Virtual Assistant: Accuracy and Technology providers in Indian banking sector}

With the introduction of chatbots in banking sector, it is important that the chatbots responses must be accurate. This will not only help the customers gain confidence on usage of chatbots but will also help the bank in reduction of customer traffic in bank branches. Data related to accuracy of the banks chatbot was collected from different sources and is reflected in table 6.3. Though the data for accuracy of chatbots is not available for all banks but amongst the banks for which data is available, the City Union Bank's chatbot accuracy has been $95 \%$. Apart from the accuracy, another important factor, is the availability of the chatbot services. Though most of the banks have claimed that their chatbots are available round the clock but data related to same is not available in public domain. Only HDFC bank has provided the data about the uptime of chatbot server and the same is around $99.9 \%$, which is quite high. The banks have implemented the chatbot functionality majorly with the support from external vendors which specializes in the particular domain.

Table 3. Technology Partners and Accuracy of Chatbots

\begin{tabular}{|l|l|l|l|l|}
\hline $\begin{array}{c}\text { SI } \\
\text { No }\end{array}$ & Bank Name & \multicolumn{1}{|c|}{ Technology Provided by } & Accuracy & \multicolumn{1}{|l|}{ Uptime } \\
\hline 1 & SBI & Payjo, Bengaluru & NA & NA \\
\hline 2 & HDFC Bank & Senseforth, Bengaluru & $85 \%$ & $99.9 \%$ \\
\hline 3 & ICICl Bank & $\begin{array}{l}\text { Combined partnership of internal } \\
\text { team, an unnamed fintech and an } \\
\text { unnamed international tech player. }\end{array}$ & $90 \%$ & NA \\
\hline 4 & Yes Bank & Not provided & NA & NA \\
\hline 5 & Induslnd Bank & Not provided & NA \\
\hline 6 & Kotak Bank & Nuance, USA & $93 \%$ & NA \\
\hline 7 & Axis Bank & Active.ai, Singapore & NA \\
\hline 8 & $\begin{array}{l}\text { City Union } \\
\text { Bank }\end{array}$ & Softbank, Japan & NA \\
\hline 9 & Andhra Bank & FloatBot, Bengaluru & NA \\
\hline 10 & Bank of Baroda & NA & NA & NA \\
\hline 11 & $\begin{array}{l}\text { Union Bank of } \\
\text { India }\end{array}$ & NA & NA \\
\hline 12 & Canara Bank & $\begin{array}{l}\text { Invento Robotics, Bengaluru and } \\
\text { Softbank, Japan }\end{array}$ & NA & NA \\
\hline${ }^{*}$ NA - Not Available & & & \\
\hline
\end{tabular}


Singh N.P. \& Singh D.: Chatbots and Virtual Assistant in Indian Banks

Table 4. Question asked to the chatbot and Answer Obtained

\begin{tabular}{|c|c|c|c|c|c|}
\hline SI No & $\begin{array}{l}\text { Name of } \\
\text { Bank }\end{array}$ & $\begin{array}{l}\text { Chatbot } \\
\text { Name }\end{array}$ & Question asked & Answer given by chatbot & $\begin{array}{l}\text { Is the } \\
\text { answer } \\
\text { correct? }\end{array}$ \\
\hline 1 & $\begin{array}{l}\text { HDFC } \\
\text { Bank }\end{array}$ & EVA & $\begin{array}{l}\text { who is the CEO } \\
\text { of HDFC bank }\end{array}$ & $\begin{array}{l}\text { Mr. Aditya Puri is the } \\
\text { Managing Director of HDFC } \\
\text { Bank. }\end{array}$ & Yes \\
\hline 2 & $\begin{array}{l}\mathrm{ICICI} \\
\text { Bank }\end{array}$ & $\mathrm{iPal}$ & $\begin{array}{l}\text { who is the CEO } \\
\text { of ICICI Bank }\end{array}$ & $\begin{array}{ll}\text { Please select from below } & \text { Lption:Car } \\
\text { Commercial Vehicle Loans }\end{array}$ & No \\
\hline 3 & Yes Bank & $\begin{array}{l}\text { Yes } \\
\text { Robot }\end{array}$ & $\begin{array}{l}\text { Who is the } \\
\text { CEO of Yes } \\
\text { Bank }\end{array}$ & $\begin{array}{l}\text { Mr. Ravneet Gill is MD \& } \\
\text { CEO of YES BANK. }\end{array}$ & Yes \\
\hline 4 & $\begin{array}{l}\text { Indusind } \\
\text { Bank }\end{array}$ & $\begin{array}{l}\text { Indusassi } \\
\text { st }\end{array}$ & $\begin{array}{l}\text { Who is the } \\
\text { CEO of } \\
\text { Induslnd Bank }\end{array}$ & $\begin{array}{l}\text { Sorry, I am unable to handle } \\
\text { your query }\end{array}$ & No \\
\hline 5 & $\begin{array}{l}\text { Kotak } \\
\text { Mahindra } \\
\text { Bank }\end{array}$ & Keya & $\begin{array}{l}\text { Can you tell me } \\
\text { who is the CEO } \\
\text { of Kotak Bank }\end{array}$ & $\begin{array}{l}\text { Mr.Uday Kotak is the } \\
\text { Executive Vice Chairman } \\
\text { and Managing director of } \\
\text { the Bank }\end{array}$ & Yes \\
\hline 6 & Axis Bank & Axis Aha & $\begin{array}{l}\text { Can you tell me } \\
\text { who is the CEO } \\
\text { of axis bank }\end{array}$ & $\begin{array}{l}\text { Please Click here to know } \\
\text { about our MD and CEO.(On } \\
\text { migration to the suggested } \\
\text { page the details were } \\
\text { available) }\end{array}$ & $\begin{array}{l}\text { Answer } \\
\text { was not } \\
\text { direct }\end{array}$ \\
\hline 7 & $\begin{array}{l}\text { City Union } \\
\text { Bank }\end{array}$ & $\begin{array}{l}\text { CUB } \\
\text { Lakshmi } \\
\text { Robot }\end{array}$ & $\begin{array}{l}\text { Who is the } \\
\text { CEO of City } \\
\text { Union Bank }\end{array}$ & $\begin{array}{l}\text { Visit CUB Executive Profile } \\
\text { Page.(On migration to the } \\
\text { suggested page the details } \\
\text { were available) }\end{array}$ & $\begin{array}{l}\text { Answer } \\
\text { was not } \\
\text { direct }\end{array}$ \\
\hline 8 & $\begin{array}{l}\text { State } \\
\text { Bank of } \\
\text { India }\end{array}$ & SIA & $\begin{array}{l}\text { Who is the } \\
\text { chairman of } \\
\text { SBI }\end{array}$ & $\begin{array}{l}\text { I am sorry, I am unable to } \\
\text { response your query. } \\
\text { Please Call SBI's } 24 X 7 \\
\text { helpline number i.e. } 180011 \\
2211 \text { (toll-free), } 1800425 \\
3800 \text { (toll-free) or } 080- \\
26599990 \text { Toll free } \\
\text { numbers are accessible } \\
\text { from all landlines and mobile } \\
\text { phones in the country. }\end{array}$ & $\mathrm{NO}$ \\
\hline 9 & $\begin{array}{l}\text { Andhra } \\
\text { Bank }\end{array}$ & $\mathrm{ABHi}$ & $\begin{array}{l}\text { Who is the } \\
\text { CEO of Andhra } \\
\text { Bank }\end{array}$ & Shri J Packirisamy & Yes \\
\hline 10 & $\begin{array}{l}\text { Bank of } \\
\text { Baroda }\end{array}$ & ADI & $\begin{array}{l}\text { Can you tell me } \\
\text { who is the CEO } \\
\text { of Bank of } \\
\text { Baroda }\end{array}$ & $\begin{array}{l}\text { I didn't understand. You can } \\
\text { try rephrasing. }\end{array}$ & No \\
\hline 11 & $\begin{array}{l}\text { Union } \\
\text { Bank of } \\
\text { India }\end{array}$ & UVA & & $\begin{array}{l}\text { Could not type in any } \\
\text { specific question. The } \\
\text { chatbot accepts inputs from } \\
\text { pre-selected tabs }\end{array}$ & No \\
\hline 12 & $\begin{array}{l}\text { Canara } \\
\text { Bank }\end{array}$ & $\begin{array}{l}\text { Mitra and } \\
\text { Candi } \\
\text { Robot }\end{array}$ & & $\begin{array}{l}\text { Could not ask these are } \\
\text { robots in the branch }\end{array}$ & $\begin{array}{l}\text { Not } \\
\text { Applica } \\
\text { ble }\end{array}$ \\
\hline
\end{tabular}


Table 4 contains the data of one question asked to different chatbots / virtual assistants of Indian banks. Table 5. contains the data of the same question asked to Alexa. It is evident from the data given in these two tables that accuracy of chatbots/ virtual assistant is not at par with Alexa. Alexa answered the same question with respect to different banks correctly but answers of many chatbots are either wrong or understanding of the question is very low.

Table 5. Question asked to the Alexa and Answer Obtained

\begin{tabular}{|c|c|c|c|c|}
\hline $\begin{array}{l}\text { SI } \\
\text { No }\end{array}$ & $\begin{array}{l}\text { Name of } \\
\text { Bank }\end{array}$ & Question asked & Answer given by Alexa & $\begin{array}{c}\text { Is the } \\
\text { answer } \\
\text { correct? }\end{array}$ \\
\hline 1 & HDFC Bank & $\begin{array}{l}\text { who is the CEO of HDFC } \\
\text { bank }\end{array}$ & $\begin{array}{l}\text { HDFC Bank's Chief } \\
\text { executive Officer is Aditya } \\
\text { Puri. }\end{array}$ & Yes \\
\hline 2 & ICICI Bank & $\begin{array}{l}\text { who is the CEO of } \mathrm{ICICl} \\
\text { Bank }\end{array}$ & $\begin{array}{l}\text { Sandeep Bakhshi is the } \\
\text { CEO of ICICI Bank }\end{array}$ & Yes \\
\hline 3 & Yes Bank & $\begin{array}{l}\text { Who is the CEO of Yes } \\
\text { Bank }\end{array}$ & $\begin{array}{l}\text { Ravneet Gill is the CEO of } \\
\text { Yes Bank }\end{array}$ & Yes \\
\hline 4 & $\begin{array}{l}\text { IndusInd } \\
\text { Bank }\end{array}$ & $\begin{array}{l}\text { Who is the CEO of } \\
\text { Indus Ind Bank }\end{array}$ & $\begin{array}{l}\text { Romesh Sobti is the CEO } \\
\text { of Indusind Bank }\end{array}$ & Yes \\
\hline 5 & $\begin{array}{l}\text { Kotak } \\
\text { Mahindra } \\
\text { Bank }\end{array}$ & $\begin{array}{l}\text { Who is the CEO of Kotak } \\
\text { Bank }\end{array}$ & $\begin{array}{l}\text { Uday Kotak is the CEO of } \\
\text { Kotak Mahindra Bank }\end{array}$ & Yes \\
\hline 6 & Axis Bank & $\begin{array}{l}\text { Who is the CEO of Axis } \\
\text { bank }\end{array}$ & $\begin{array}{l}\text { Amitabh Chaudhry is the } \\
\text { CEO of Axis Bank }\end{array}$ & Yes \\
\hline 7 & $\begin{array}{l}\text { City Union } \\
\text { Bank }\end{array}$ & $\begin{array}{l}\text { Who is the CEO of City } \\
\text { Union Bank }\end{array}$ & $\begin{array}{l}\text { N.Kamakodi is the CEO of } \\
\text { City Union Bank }\end{array}$ & Yes \\
\hline 8 & $\begin{array}{l}\text { State Bank } \\
\text { of India }\end{array}$ & $\begin{array}{l}\text { Who is the chairman of } \\
\text { SBI }\end{array}$ & $\begin{array}{l}\text { State Bank of India's chair } \\
\text { is Rajnish Kumar }\end{array}$ & Yes \\
\hline 9 & $\begin{array}{l}\text { Andhra } \\
\text { Bank }\end{array}$ & $\begin{array}{l}\text { Who is the CEO of } \\
\text { Andhra Bank }\end{array}$ & $\begin{array}{l}\mathrm{J} \text { Packirisamy is the CEO } \\
\text { of Andhra Bank }\end{array}$ & Yes \\
\hline 10 & $\begin{array}{ll}\text { Bank } & \text { of } \\
\text { Baroda } & \\
\end{array}$ & $\begin{array}{l}\text { Who is the CEO of Bank } \\
\text { of Baroda }\end{array}$ & $\begin{array}{l}\text { P. Jayakumar is the CEO } \\
\text { of Bank of Baroda }\end{array}$ & Yes \\
\hline 11 & $\begin{array}{l}\text { Union Bank } \\
\text { of India }\end{array}$ & $\begin{array}{l}\text { Who is the CEO of Union } \\
\text { Bank of India }\end{array}$ & $\begin{array}{l}\text { Rajkiran Rai G, is the CEO } \\
\text { of Union Bank of India }\end{array}$ & Yes \\
\hline 12 & $\begin{array}{l}\text { Canara } \\
\text { Bank }\end{array}$ & $\begin{array}{l}\text { Who is the CEO of } \\
\text { Canara Bank }\end{array}$ & $\begin{array}{l}\text { R.Narayanan is the CEO } \\
\text { of Canara Bank }\end{array}$ & Yes \\
\hline
\end{tabular}

Table 6 presents the data of select banks at Facebook. It is evident from the data given in Table 6 that State Bank of India (SBI) presence on Facebook is more than any other bank in India. Yes Bank is second in the rank. 
Singh N.P. \& Singh D.: Chatbots and Virtual Assistant in Indian Banks

Table 6. Selected Indian Bank at Facebook (14 $4^{\text {th }}$ Nov 2019)

\begin{tabular}{|l|l|l|r|r|}
\hline S.N. & \multicolumn{1}{|c|}{ Bank Name } & \multicolumn{1}{c|}{ Date of Joining } & \multicolumn{1}{c|}{ Like } & \multicolumn{1}{c|}{} \\
\hline 1 & State Bank of India & January 2, 2013 & $18,122,047$ & $18,119,945$ \\
\hline 2 & HDFC Bank & August 26, 2010 & $2,806,254$ & $2,796,512$ \\
\hline 3 & ICICI Bank & December 16, 2011 & $5,469,175$ & $5,452,175$ \\
\hline 4 & Yes Bank & February 17, 2010 & $7,188,819$ & $7,168,053$ \\
\hline 5 & IndusInd Bank & August 23, 2012 & $1,585,428$ & $1,586,379$ \\
\hline 6 & Kotak Mahindra Bank & June 27, 2011 & $1,519,277$ & $1,586,982$ \\
\hline 7 & Axis Bank & June 8, 2011 & $3,692,712$ & $3,695,254$ \\
\hline 8 & City Union Bank & November 6, 2014 & 3,715 & 3,840 \\
\hline 9 & Andhra Bank & September 29, 2015 & 54,027 & 54,375 \\
\hline 10 & Bank of Baroda & December 30, 2015 & $1,423,844$ & $1,429,016$ \\
\hline 11 & Union Bank of India & October 14, 2016 & $1,412,905$ & $1,414,758$ \\
\hline 12 & Canara Bank & May 22, 2019 & 4,980 & 5,088 \\
\hline
\end{tabular}

\subsection{Brief description of Indian banking chatbots/ virtual assistants}

State bank of India: SBI has deployed the chatbot named SIA. It is an artificial intelligence -powered software that has the capability to respond to 864 million queries a day, making it the largest-financial sector. SIA has been set up to handle nearly 10,000 enquiries per second. It is nearly 25 per cent of the queries processed by Google. The bank is expected to see a significant reduction in operational expenditure overtime (Livemint, 2017). Deployment of this size is perhaps the first of its kind in India and across the world (Sharma, 2018). This Al banking platform has been provided by Payjo. Payjo is based out of Silicon Valley in US and Bengaluru. SIA or SBI Intelligent Assistant is a multilingual chatbot which can respond in 14 languages in speech or text. Initially, it will provide responses to standard queries like information on products and services and responding to frequently asked questions like ATM locations and IFSC codes (PTI, 2017).

HDFC Bank: HDFC Bank's EVA (Electronic Virtual Assistant) is India's first and largest Artificial Intelligence powered banking chatbot. Eva was built with the aim to leverage latest technologies to help serve the bank's customers better and faster. Eva uses the latest in Al and Natural Language Processing to understand the user query and fetch the relevant information from thousands of possible sources, all in a matter of milliseconds. Customers can get the information they are seeking instantaneously by conversing with Eva in human language instead of searching, browsing, clicking buttons or waiting on a call. Eva has already answered more than 5 million queries from around a million customer with more than $85 \%$ accuracy. The numbers of queries 
answered till March 11, 2018 were 5.5. million (Das, 2018). The numbers of queries answered till April 27, 2018 were 6.5 million (Maru, 2018). Eva holds more than 20,000 conversations everyday with customers from all over the world. The technology behind Eva was built and is managed by Senseforth Al Research Private Limited (Source: HDFC Bank Website). According to another source chatbot had handled 16 million conversations with an accuracy of over $90 \%$ and chatbot has been configured to handle queries on more than 7,500 FAQs, along with information on the bank's products and services (Dastur, 2019). Login to internet banking is not needed for asking questions to Eva. Authors asked account balance. Eva requested registered mobile phone number with bank. It is verified with an OTP. If the customer has registered to Bank's SMS service, then the customer will get balance otherwise an advice to go for internet banking or ATM.

ICICI Bank: ICICl Bank's has deployed the chatbot with name iPal. It is an Artificial Intelligence (Al)-powered chatbot and has completed 6 million responses. It has interacted with 3.1 million customers in eight months of its implementation (Bank website) and handles around one million queries monthly on both website and mobile apps, providing resolutions to customers round the clock (Maru, 2017). The chatbot has been built with a partnership between bank internal team, a fintech firm and an international tech firm. The Chatbot had answered queries with $90 \%$ accuracy. $\mathrm{ICICl}$ is planning that its chatbot should support for vernacular languages, voice support and API integration with platforms like the Google Assistant, Siri, Facebook messenger (Mukherjee, 2017). Mukherjee (2017) further reported that VA of ICICI Bank will answer your account balance promptly. On the contrary it does not answer this question directly.

Yes Bank: The bank has launched the chatbot with name YES ROBOT. It is an Al powered chatbot. The bot combines natural language processing and artificial intelligence in order to offer a human like experience for customers while using banking services. The chatbot is able to handle around half a million customer interactions every month while offering over 25 banking services (Press Release, 2019). The bank is partnering with Microsoft to strengthen its chatbot with advanced natural language processing engine called LUIS (Language Understanding Intelligent Service) and other cognitive services. One of the most pivotal features of this chatbot is the option to book fixed deposits (FDs) and recurring deposits (RDs) by simply conversing with it, without the need of registration or remembering passwords (only OTP based authentication is required) (Microsoft News Center India, 2019). As per Bank, the use of $\mathrm{Al}$ and machine learning integrated into enterprise solutions impacts the productivity of people, which has great returns on both the topline growth and bottom-line savings. The primary intent is to reduce cost of operations and secondly to improve customer experience and increase 
efficiency. Since December, 2018 Rs. 9.2 billion worth deposits have been booked through YES ROBOT, which suggests that the bot has gained acceptance from the customers. Even with human errors, the chatbot can identify the intent of the user with over 90 percent accuracy and over 9.8 million customer interactions have already been reported on YES ROBOT since its launch (ETCIO, 2019). James, 2019) reported that Yes bank plans to integrate other features in to Robot. These features are voice-based commands, which will be interfaced with a data lake comprising 360-degree customer information to further enhance user experience.

IndusInd Bank: The IndusInd bank has launched the chatbot with name Indusassist. The chatbot is an Al-powered chatbot. The bank has partnered with Amazon's Alexa in order to enable the customer to avail banking services by simply talking to Alexa. Customers can perform financial and non-financial banking transactions on Amazon Echo and other Alexa enabled devices using voice-based commands using the chatbot (Press Release, 2018). The bank has also stated that the transactions done through this mode are completely safe and secure as it uses the 2-factor authentication guidelines prescribed by the regulator (Livemint, 2018). Integration of their chatbot "Indusassist" with Alexa is an attempt of the bank to take the banking beyond the banking channels to the Internet of Things (TechHerald Bureau, 2018). Data related to number of queries handled/responded by the chatbot is not available in public domain. The bank has also not revealed the name of its technology partner.

Kotak Bank: The bank has launched the chatbot with name Keya. The chatbot since its launch has handled 3.5 million queries from over 1 million unique users with $93 \%$ accuracy. The chatbot has been built by the Nuance, which a US based technology firm (Media Release, 2018, 2019). Bhakta (2018b) reported that Keya uses automatic speech recognition, natural language understanding and text-to-speech technology to help customers navigate smoothly and quickly through the IVR. Further to it, Keya understands the caller's intent, verifies it and then offers relevant solutions resulting in greater call routing accuracy, reduced call duration and improved customer satisfaction. Active.ai (2019) reported that Keya had answered more than 3.5 million queries from over 1 million unique users with $93 \%$ accuracy.

Axis Bank: The bank has implemented the chatbot with name Aha. The chatbot has been launched in partnership with Singapore based tech firm, Active.Ai. The chatbot is Al based. The bank has seen a surge in usage of its conversational Al platform chatbot on their mobile banking app which has over 10 million customers (Asiaone, 2019). The chatbot is one of the advanced versions in the Indian banking industry as it is not only capable of answering the customers queries through voice and text but is also able to execute actual transactions like blocking card and doing recharge (Parwatay, 
2019). Axis Aha brings the power of machine learning and artificial intelligence. It is capable of transferring funds, ordering a cheque book, clearing credit card and utility bills, enhancing debit card limits and switching off debit card temporarily (PersonalFN, 2018).

City Union Bank: The chatbot implemented by the bank is with the name CUB Lakshmi. The chatbot is able to answer customers' queries related to balances, interest rates and payments. The bot is continuously learning from the customer's interactions and uses this experience to serve the customers in an efficient way in future (Hamilton, 2016. Andreasyan, 2016). The chatbot is currently handling her range of roles with a response accuracy of over $95 \%$ on the content that she is trained on. She is also continually improving as she addresses at least over 1,00,000 customer queries per month. The technology partner for the implementation of chatbot is Softbank, Japan (DQC Bureau, 2018). Necessary data security measures are also added to the bot (Mishra, 2019).

Andhra Bank: The bank launched the chatbot with name $\mathrm{ABHi}$. Bangalore based Al start up, Floatbot has launched Al Chatbot integrated with Core Banking Servers of Andhra Bank, to digitally engage and automate customer support for its 5 Crore customers. Floatbot has launched the chatbot for Andhra Bank after going through end to end security audit and a rigorous user acceptance testing (UAT). More than 50,000 queries were tested before the final sign-off (The SME Times News Bureau, 2019). The chatbot uses artificial intelligence and natural language processing to understand the customers' input and fetch the related information from the knowledgebase in milliseconds (Hans News Service, 2019). The chatbot as of now deals with only customer queries but the future plan is to extend the chatbot to address more service like balance check, ordering cheque book, viewing mini statement and getting recent transactions. The chatbot will also be able to converse with customers over WhatsApp (UNI, 2019).

Bank of Baroda: The bank has launched the chatbot with name ADI (Assisted Digital Interaction), which is powered by IBM Watson's API (Infotechlead, 2018). Data related to technology partner and number of queries responded/handled by the chatbot is not available yet in public domain. The bank believes that chatbots are an important addition to robotics process automation. The bank also mentioned that the chatbot handles the queries related to products (Dash, 2018).

Union Bank of India: The bank has launched the chatbot with name UVA. The chatbot was launched on $99^{\text {th }}$ foundation day of the bank (Press Release, 2017). Apart from this the bank has not provided much details in the public 
domain. Data related to technology partner and number of queries responded/handled by the chatbot is not available yet in public domain.

Canara Bank: The bank has launched two robots in their bank premises to handle the customer queries. The name of these robots is Mitra and CANDI. Mitra is developed by Invento Robotics, Bangaluru and CANDI is developed by Softbank, Japan. Data related to number of queries responded/handled by the chatbot is not available yet in public domain. The bank has gone ahead and started using the vernacular language i.e. Kannada. Apart from performing the tasks of query handling the bot is capable to perform as a security guard. The bot has a HD camera and remains vigilant through the night (Thomas, 2017). CANDI has two different modes of operation i.e. normal and banking. In normal mode, it can respond to a big range of question. In banking mode it can respond to 215 questions (Patranobis and Gopal, 2017).

\section{Analysis, Results and Recommendations}

In order to keep themselves abreast of the competition it is important to remain ahead in the technology banks are aggressively investing on emerging technologies across the globe. However, there is still a lot of ground to cover in terms of adoption of emerging technologies like Al powered chatbots/virtual assistants in India which is evident from the analysis of three sets of data collected for answering research questions in this article.

What is present status of chatbots/virtual assistant's implementation by Indian Banks? Only 14 banks out of large number of banks as listed in first para of introduction have either implemented or planning to implement chatbots/ virtual assistants in India. It means these technologies are not yet very popular among Indian banks. Secondly, out of 55 employees contacted, only 15 were aware of chatbots/ virtual assistants.

What are the ways to connects chatbots/ virtual assistants implemented by Indian Banks? The ways to connect chatbots / virtual assistants are Bank's Website, Google Assistant, Amazon Alexa, mobile bank applications, Facebook Messenger, and at the bank premises. This question is technical; therefore, employees were not asked to answer it.

What are the services offered by chatbots/virtual assistants implemented by Indian Banks? Most of the banks are offering answers to general queries as listed in the section 6. However, employees of the banks at service counter are not much aware of services offered by the banks to the customers. On the other hand, internet blogs, press releases by the banks and technology 
providers mentioned large number of services such as clearing of checks in less time, Know Your Customer (KYC) verification in less time etc.

What is the level of accuracy by chatbots/virtual assistants implemented by Indian Banks? As evident from the data given in earlier sections, the accuracy of chatbots/ virtual assistants is not very high. Data with respect to the performance of chatbots/ virtual assistants is not revealed by the banks or technology provider.

Considering the length and breadth of Indian continent and the diverse population in terms of language, income groups, gender and education level it is important to provide chatbot/ virtual assistants solutions which can cater to the needs to the diverse population with highest accuracy, with ease of use and in less time. It is suggested that (i) implementation of these technologies should be done keeping in view the different strata of the customers, (ii) cost of the technologies vis-à-vis tangible benefits, (iii) security concerns, (iv) future level of usage, (v) impact on overall operational and financial performance of the banks, and (vi) adding need base features in the existing Al based technologies. Further, banks must develop benchmarks for maximum and minimum investment (Total cost of operations) in information technologies as the percentage of turn over, profits or any other financial parameter.

\section{References}

Active.ai (2019). Active.ai powers Kotak Mahindra bank's conversational Al chatbot, July 02. Retrieved on August 15, 2019 from https://www.prnewswire.com/in/news-releases/active-ai-powers-keya-kotakmahindra-bank-s-conversational-ai-chatbot-830058711.html.

Andreasyan, T. (2016). Lakshmi, India's first banking robot, unveiled by City Union Bank, November 13. Retrieved on December 25, 2019 from https://www.fintechfutures.com/2016/11/lakshmi-indias-first-banking-robotunveiled-by-city-union-bank/

Asiaone (2019). Axis Aha! surges with over 10 million Conversational Engagement, June 12. Retrieved on August 11, 2019 from https://active.ai/2019/06/12/axisaha-surges-with-over-10-million-conversational-engagement/.

Bhakta, P. (2018a). Federal Bank launches chatbot for easy m-commerce on its mobile app, January 22. Retrieved on August 12, 2019 from https://economictimes.indiatimes.com/small-biz/startups/newsbuzz/federalbank-launches-chatbot-for-easy-m-commerce-on-its-mobileapp/articleshow/62604376.cms.

Bhakta, P. (2018b). Kotak Mahindra Bank launches new Al powered voice bot, April 02. Retrieved on August 15, 2019 from https://economictimes.indiatimes.com/industry/banking/finance/banking/ kotakmahindra-bank-launches-new-ai-powered-voicebot/articleshow/63582558.cms?from $=\mathrm{mdr}$. 
Singh N.P. \& Singh D.: Chatbots and Virtual Assistant in Indian Banks

Bhakta, P. (2019). Debit card POS swipes rise $27 \%$ as per RBI data, May 18 Retrieved on August 16, 2019 from https://economictimes.indiatimes.com/industry/banking/finance/banking/debitcard-pos-swipes-rise-27-as-per-rbi-data/articleshow/69382225.cms.

Bluewolf.com (2019). 7 characteristics of a great chatbot, Retrieved on December 11, 2019 from https://www.bluewolf.com/bluewolf-now/7-characteristics-greatchatbot

Business wire (2018). Global Intelligent virtual assistant market 2018-2023, July 23. Retrieved on November 12, 2019 from https://www.businesswire.com/news/home/20180723005506/en/GlobalIntelligent-Virtual-Assistant-Market-2018-2023-Market

Chitra, R. (2019). Banks use Al everywhere, from chatbots to validating cheques, July 16. Retrieved on August 08, 2019 from https://timesofindia.indiatimes.com/business/india-business/banks-use-aieverywhere-from-chatbots-to-validating-cheques/articleshow/70237317.cms.

Das. G. (2018). Sensdorth making smart bots, March 11. Retrieved on August 11, 2019 from https://www.businesstoday.in/buzztop/buzztop-feature/senseforthmaking-smart-bots/story/270969.html.

Dash S (2018). Does the Future of Indian Banking Lie in Chatbots? April 11. Retrieved on December 15, 2019 from https://www.entrepreneur.com/article/311795.

Dastur, Z. (2019). Conversational Al for banking chatting about Eva and IRA, July 22. Retrieved on August 15, 2019 from https://lucep.com/conversational-ai-forbanking-chatting-about-eva-and-ira/.

Dias, A. (2019). A detailed insight on working of chatbots, July 16. Retrieved on December 11, 2019 from https://www.weblineglobal.com/blog/a-detailed-insighton-working-of-chatbots/

DQC Bureau (2018). CASE STUDY: City Union Bank Envisions its Integrated RoboBanking Ambitions, Jun, 28. Retrieved on August 1, 2019 from https://www.dqchannels.com/case-study-city-union-bank-envisions-integratedrobo-banking-ambitions/.

ETCIO (2019). Yes Bank bets big on Al bots as potential revenue creators. Retrieved on December 15, from https://cio.economictimes.indiatimes.com/news/strategy-and-management/yesbank-bets-big-on-ai-bots-as-potential-revenue-creators/71680206.

Gupta, A., \& Sharma, D. (2019). Customers' Attitude towards Chatbots in Banking Industry of India. International Journal of Innovative Technology and Exploring Engineering (IJITEE), 8(11): 1222- 1225

Hans News Service (2019). Andhra Bank unveils Al chatbot ABHi, July15. Retrieved on December 15, 2019 from https://www.thehansindia.com/business/andhrabank-unveils-al-chatbot-abhi-546877.

Himlton, A. (2016). City Union Bank launches Lakshmi branch bot. Retrieved on December 15, 2019 from https://ibsintelligence.com/ibs-journal/ibs-news/cityunion-bank-launches-lakshmi-branch-bot/.

Hoffer, R. (2016). The trouble with bots: A parent's musings on SmarterChild, June 05. Venture Beat. Retrieved on December 22, 2019 from https://venturebeat.com/2016/06/15/the-trouble-with-bots-a-parents-musingson-smarterchild/ 
Infotechlead (2018). IBM inks IT deal with Bank of Baroda for digital transformation. Retrieved on December 11, 2019 from https://infotechlead.com/mobility/ibminks-it-deal-with-bank-of-baroda-for-digital-transformation-55191.

Jain, M., \& Kumar, P., Kota, R., \& Patel, S. N. (2018). Evaluating and Informing the Design of Chatbots. Proceedings of the 2018 on Designing Interactive Systems Conference 2018 - DIS '18.

James, L. (2019). Yes Bank creates 'Yes Robot' using Microsoft cognitive services, September 27. Retrieved on December 25, 2019 from https://www.technologyrecord.com/Article/yes-bank-creates-yes-robot-usingmicrosoft-cognitive-services-87198

Kim, L. (2018). 8 Characteristics All Facebook Messenger Chatbots Should Have retrieved on December 11, 2019 from https://www.inc.com/larry-kim/8characteristics-all-facebook-messenger-chatbots-should-have.html

Kuligowska, K. (2015). Commercial Chatbot: Performance Evaluation, Usability Metrics and Quality Standards of Embodied Conversational Agents (February 5, 2015). Professionals Center for Business Research.

Livemint (2018). IndusInd Bank customers can now use voice-based command through Alexa for banking services. Retrieved on December 15, 2019 from https://www.livemint.com/Companies/ABtZPmpcb88SWsafME331M/IndusIndBank-customers-can-now-use-voicebased-command-thro.html.

Livemint (2017). SBI launches chatbot to help customers in banking services, September 25. Retrieved on December 15, 2019 from https://www.livemint.com/Industry/68ipadKiLQwxGUKTxXd3pL/SBI-launcheschatbot-to-help-customers-in-banking-services.html.

Lynskey, D. (2019). Alexa, are you invading my privacy? - the dark side of our voice assistants, October 9. Retrieved on December 25, 2019 from https://www.theguardian.com/technology/2019/oct/09/alexa-are-you-invadingmy-privacy-the-dark-side-of-our-voice-assistants

Maru P (2017). ICICl Bank's Al chatbot iPal empowers customers with information and financial services, October 2017. Retrieved on August 11, 2019 from https://cio.economictimes.indiatimes.com/news/enterprise-services-andapplications/icici-banks-ai-chatbot-ipal-empowers-customers-with-informationand-financial-services/61118452.

Maru, P. (2018). HDFC bank launches IRA 2.0 the advance version of its interactive humanoid, April 27. Retrieved on August 11, 2019 from https://cio.economictimes.indiatimes.com/news/enterprise-services-andapplications/hdfc-bank-launches-ira-2-0-the-advance-version-of-its-interactivehumanoid/63936738.

Maya, S. (2017). Top 10 features your chatbot must have. Retrieved on December 11, 2019 from https://murraynewlands.com/2017/11/top-10-features-your-chatbotmust-have/

McTear, M., Callejas, Z., and Griol, D. (2016). Creating a Conversational Interface Using Chatbot Technology. The Conversational Interface, 125-159.

Media Release (2018). Kotak Mahindra Bank launches Keya - the First Voice bot in Indian Banking Bank Press Release April,02. Retrieved on August 11, 2019 from https:/www.kotak.com/content/dam/Kotak/about-us/media-pressreleases/2018/kotak-mahindra-bank-launches-keya-the-first-voicebot-in-indianbanking-02042018.pdf 
Media Release (2019). Kotak Mahindra Bank Launches Keya 2.0 Indian Banking's First Voicebot gets Upgraded with Al-powered Conversational Banking, July, 01. Retrieved on August 11, 2019 from https://www.kotak.com/content/dam/Kotak/about-us/media-pressreleases/2019/media-release-kotak-mahindra-bank-keya.pdf.

Microsoft News Center India (2019). YES, Bank bets big on Al; partners Microsoft to strengthen its Al powered banking solutions, September 04. Retrieved on December 24, 2019 from https://news.microsoft.com/en-in/yes-bank-partnersmicrosoft-ai-powered-banking-solutions/

Mishra A (2019). Meet Lakshmi- your new self-service aid, October 18. Retrieved on December $15, \quad 2019$ from https://cio.economictimes.indiatimes.com/dobig/news/detail/1246.

Mukherjee, A. (2017). ICICI bank's chatbot iPal can take care of your banking needs, Retrieved on August 10, 2019 from https://www.digit.in/news/general/icicibanks-chatbot-ipal-can-take-care-of-your-banking-needs-37627.html.

News Release (2013). IBM Watson hard at work: New breakthroughs transform quality care for patients, February 08. Retrieved on December 23, 2019 from https://www-03.ibm.com/press/us/en/pressrelease/40335.wss

Parwatay, S. (2019). Chatbots are the future, April 10. Retrieved on December 15, 2019 from https://www.axisbank.com/progress-with-us/tech-talk/chatbots-arethe-future.

Patranobis, S. and Gopal, V. (2017). Mitra and candi: the robots who take care of customers at canara bank in bengaluru, September 22. Retrieved on august 07, 2019 from https://www.hindustantimes.com/india-news/meet-mitra-and-candirobots-taking-care-of-customers-at-canara-bank-in-bengaluru/storyrfeeyogms2nru5dfkc7goi.html.

Personalfn (2018). Axis aha! -making banking worth talking about, may 27. Retrieved on december 15, 2019 from https://www.axisbank.com/progress-with-us/moneymatters/axis-aha-making-banking-worth-talking-about.

Piccolo, Lara; Mensio, Martino and Alani, Harith (2019). Chasing the Chatbots: Directions for Interaction and Design Research. In: Internet Science. INSCI 2018 (Bodrunova, s ed.), Lecture Notes in Computer Science, Springer, pp. 157-169.

Pise, R. (2018). Chatbot market size set to exceed USD 1.34 billion by 2024, July 06. Retrieved on December 25, 2019 from https://www.clickz.com/chatbot-marketsize-is-set-to-exceed-usd-1-34-billion-by-2024/215518/

Press Release (2017). Union Bank celebrates $99^{\text {th }}$ foundation day, November 2017. Retrieved on August 11, 2019 from https://www.unionbankofindia.co.in/pdf/PRUnion-Bank-celebrates-99th-Foundation-Day.pdf.

Press Release (2018). IndusInd Bank launches voice based banking services through Amazon Alexa, September 25. Retrieved on December 15, 2019 from https://www.indusind.com/IndusAssistPressRelease.html.

Press Release (2019). Yes-Bank bets big on Al: Partners Microsoft to strengthen its Al powered banking solutions, September 04. Retrieved on December 15, 2019 from https://www.yesbank.in/media/press-releases/yes-bank-bets-big-on-ai.

PTI (2017). SBI launches chatbot to help customers in banking activities, September 25. Retrieved on August 03, 2019 from https://timesofindia.indiatimes.com/business/india-business/sbi-launcheschatbot-to-help-customers-in-banking-activities/articleshow/60827414.cms. 
PTI (2018). SBI other banks using Al big time to improve efficiency cut costs, July 25. Retrieved on August 16, 2019 from https://www.expresscomputer.in/news/sbiother-banks-using-ai-big-time-to-improve-efficiency-cut-costs/25611/.

Rawal, A. (2017). ICICI bank leverages iPal chatbot for customer service, December 13. Retrieved on August 09, 2019 from https://www.expresscomputer.in/news/icici-bank-leverages-ipal-chatbot-forcustomer-service/22824/.

Rollason. H. (2019). Welcome to the age of adaptive automation. Retrieved on December 11, 2019 from https://www.conversocial.com/blog/11-characteristicsof-a-super-useful-chatbot.

Sharma M (2018). Chatbot, December 27. Retrieved on December 15, 2019 from http://dataanalyticsedge.com/2018/12/27/chatbot/.

Shetty, M. (2017). SBI deploys Al-based financial solution SIA, September 26. Retrieved on August 02, 2019 from https://timesofindia.indiatimes.com/business/india-business/sbi-deploys-aibased-financial-solution-sia/articleshow/60835330.cms.

Southern M. (2019). Google assistant only holds $9 \%$ of the virtual assistant market. Retrieved on december 25, 2019 from https://www.searchenginejournal.com/google-assistant-only-holds-9-of-thevirtual-assistant-market/341321/\#close

Singh, H. (2019). Apple's siri the most popular virtual assistant with a 35 percent market share: report, december 19. Retrieved on december 22, 2019 from https://gadgets.ndtv.com/smart-home/news/apple-siri-leads-virtual-assistantmarket-share-alexa-google-assistant-cortana-report-2151436

TechHerald Bureau (2018). IndusInd Bank launches voice-based banking service via Amazon Alexa enabled devices. Retrieved on December 15, 2019 from https://techherald.in/news-analysis/indusind-bank-launches-voice-basedbanking-service-via-amazon-alexa-enabled-devices/.

The SME Times News Bureau (2019). Andhra Bank Partners with Floatbot to launch Al Virtual Assistant - Abhi (Chatbot) to digitally engage its 5 crore+ customers, July 21. Retrieved on August 11, 2019 from http://thesmetimes.com/andhrabank-partners-with-floatbot-to-launch-ai-virtual-assistant-abhi-chatbot-todigitally-engage-its-5-crore-customers/.

Thomas, M. P. (2017). Meet Mitra: Canara Bank's new robotic customer care executive. Retrieved on December 15, 2019 from https://www.theweek.in/news/sci-tech/mitra-canara-bank-robotic-customer-careexecutive.html

UNI (2019). Andhra bank launches Al chatbot in Telangana, July 15. Retrieved on August 09, 2019 from http://www.uniindia.com/andhra-bank-launches-aichatbot-in-telangana/business-economy/news/1666603.html.

Vaidyam, A. N., \& Wisniewski, H., Halamka, J. D., Kashavan, M. S., and Torous, J. B. (2019). Chatbots and Conversational Agents in Mental Health: A Review of the Psychiatric Landscape. The Canadian Journal of Psychiatry, 070674371982897.

Warren, T. (2019). What is microsoft is doing with cortana, july 25. Retrieved on december $25, \quad 2019$ from https://www.theverge.com/2019/7/25/20727129/microsoft-cortana-featuresstrategy-report. 
Singh N.P. \& Singh D.: Chatbots and Virtual Assistant in Indian Banks

Wei, C., Zhichen YU, and Fong, S. (2018). How to build a chatbot: chatbot framework and its capabilities? Proceeding of the 2018 10th international conference on machine learning and computing, 369-373.

Weizenbaum J. (1966). ELIZA-a computer program for the study of natural language communication between man and machine. Communications of the ACM $9(1): 36-45$.

Zamora, J. (2017a). Rise of the Chatbots: Finding a place for artificial intelligence in India and US. Proceedings of the 22nd International Conference on Intelligent User Interfaces Companion - IUI '17 Companion. March 13-16, 2017, Limassol, Cyprus. http://dx.doi.org/10.1145/3030024.3040201

Zamora, J. (2017b). I'm Sorry, Dave, I'm Afraid I Can't Do That. Proceedings of the 5th International Conference on Human Agent Interaction - HAl '17. October 17-20, 2017, Bielefeld, Germany. https://doi.org/10.1145/3125739.3125766 